'Prime-Jan' ('APF-8') and 'Prime-Jim' ('APF-12')

\section{Primocane-fruiting Blackberries}

John R. Clark, ${ }^{1}$ James N. Moore, ${ }^{2}$ and Jose Lopez-Medina ${ }^{3}$

Department of Horticulture, University of Arkansas, Fayetteville, AR 72701

Chad Finn ${ }^{4}$

U.S. Department of Agriculture, Agricultural Research Service, Horticultural Crops Research Laboratory, Corvallis, OR 97330

\section{Penelope Perkins-Veazie ${ }^{5}$}

U.S. Department of Agriculture, Agricultural Research Service, South Central Agricultural Research Center, Lane, OK 74555

Additional index words. Rubus, fruit breeding, small fruit
'Prime-Jan' ('APF-8') and 'Prime-Jim' ('APF-12') are the first commercial cultivars of primocane-fruiting blackberry (Rubus L. subgenus Rubus). This unique type of blackberry fruit on current-season canes (primocanes) and second-season canes (floricanes). All other existing blackberry cultivars fruit only on floricanes, requiring canes to be overwintered to produce a crop. This new type of fruiting habit has the potential to revolutionize blackberry production much like that occurring in primocane-fruiting red raspberries (Rubus ideaus L.). These primarily for home-garden production, and for limited commercial trial evaluations.

\section{Origin}

'Prime-Jan' resulted from a cross of Ark.1836× 'Arapaho'(Fig. 1), and 'Prime-Jim' resulted from 'Arapaho' $\times$ Ark. 830 (Fig. 2). The crosses were made in 1994 at the University of Arkansas Fruit Substation, Clarksville, as J. L.-M. in which he was investigating inheritance of the primocane-fruiting trait (LopezMedina et al., 2000). The original plants of

Received for publication 28 Oct. 2004. Accepted for publication 5 Dec. 2004. We thank Kenda Woodburn, Manjula Carter, Eric Stafne, Effie Gilmore, David Gilmore, John Ridgeway, Andy Allen, Jack Young, and Paula Watson for assistance in data collection during the evaluation of 'Prime-Jan' and 'Prime-Jim'. Additional thanks are expressed to Bruce Bordelon (Purdue Univ.) Steve Stringer (U.S. Dept. of Agriculture, Small Fruit Research Station, Poplarville, Miss), and Courtney Weber (New York Agricultural Experiment Station, Geneva, N.Y.) for evaluating 'Prime-Jan' and 'Prime-Jim' at their research locations.

${ }^{1}$ Professor.

${ }^{2}$ Distinguished professor emeritus.

${ }^{3}$ Former graduate assistant. Currently research professor, Facultad de Agrobiologia, Universidad Michoacana de San Nicolas de Hidalgo, Paseo Lazaro Cardenas esquina con Berlin, Uruapan, Michoacan, 60190 Mexico.

${ }^{4}$ Research geneticist.

${ }^{5}$ Research scientist. first primocane-fruiting cultivars are intended a part of the doctoral dissertation research of these genotypes were selected in September 1997 from a seedling field at the University of Arkansas Agricultural Research and Extension Center, Fayetteville, and subsequently tested as APF-8 and APF-12. The source of the primocane-fruiting trait in these selections is the diploid cultivar 'Hillquist' which was selected in the wild in Ashland, Va., by L.G. Hillquist. Hillquist sent this genotype to Geneva, N.Y., in 1949. It was planted at the Fruit Substation, Clarksville in a germplasm block established in the early $1960 \mathrm{~s}$.

'APF-8' is the patented name of the genotype that is trademarked as 'Prime-Jan', while 'APF-12' is the patented name of the genotype that is trademarked as 'Prime-Jim'. These names were selected to honor Janita and James N. Moore. Moore founded the University of Arkansas fruit breeding program in 1964, and his wife Janita contributed to Moore's many breeding program successes.
Two, 6.1-m plots for each genotype were established at the University of Arkansas Fruit Substation, Clarksville [west-centralArkansas, lat. $35^{\circ} 31^{\prime} 58^{\prime} \mathrm{N}$ and long. $93^{\circ} 24^{\prime} 12^{\prime} \mathrm{W}$; U.S. Dept. of Agriculture (USDA) hardiness zone 7a; soil type Linker fine sandy loam (Typic Hapludults)] in late fall, 1997. Plots were established by moving the original plant along with planting root cuttings collected from each original plant. Observational data were taken on the selections in these plots after fruiting began in 1999 and continued through 2003. Single plots of comparison cultivars 'Arapaho', 'Choctaw', and 'Ouachita' were also present in this planting and observational data were collected on these during this same evaluation period. In all plantings, standard cultural practices for erect blackberry production were used including annual preemergence and postemergence herbicide applications, and annual spring $\mathrm{N}$ fertilization $\left(56 \mathrm{~kg} \cdot \mathrm{ha}^{-1}\right.$ N) using ammonium nitrate. In 2003 the primocane genotypes received application of same amount of ammonium nitrate in early July after the floricane crop was completed. The floricane-fruiting comparison cultivars had primocanes tipped at $1.1 \mathrm{~m}$ two to three times each season, and received dormant pruning of removing dead floricanes and pruning lateral branches to about $0.4 \mathrm{~m}$ in length. One of the two plots of each primocane-fruiting genotype was tipped once in late June to early July each year. Dormant pruning was also conducted on these plants to remove both dead floricanes and terminal, flower-producing tissues of primocanes. All primocane-fruiting genotypes were allowed to produce both floriand primocane crops. All plantings received a single application of liquid lime sulfur (94 $\left.\mathrm{L} \cdot \mathrm{ha}^{-1}\right)$ at budbreak for control of anthracnose [Elsinoëveneta (Burkh.) Jenkins] and this was the only fungicide applied to any plantings in

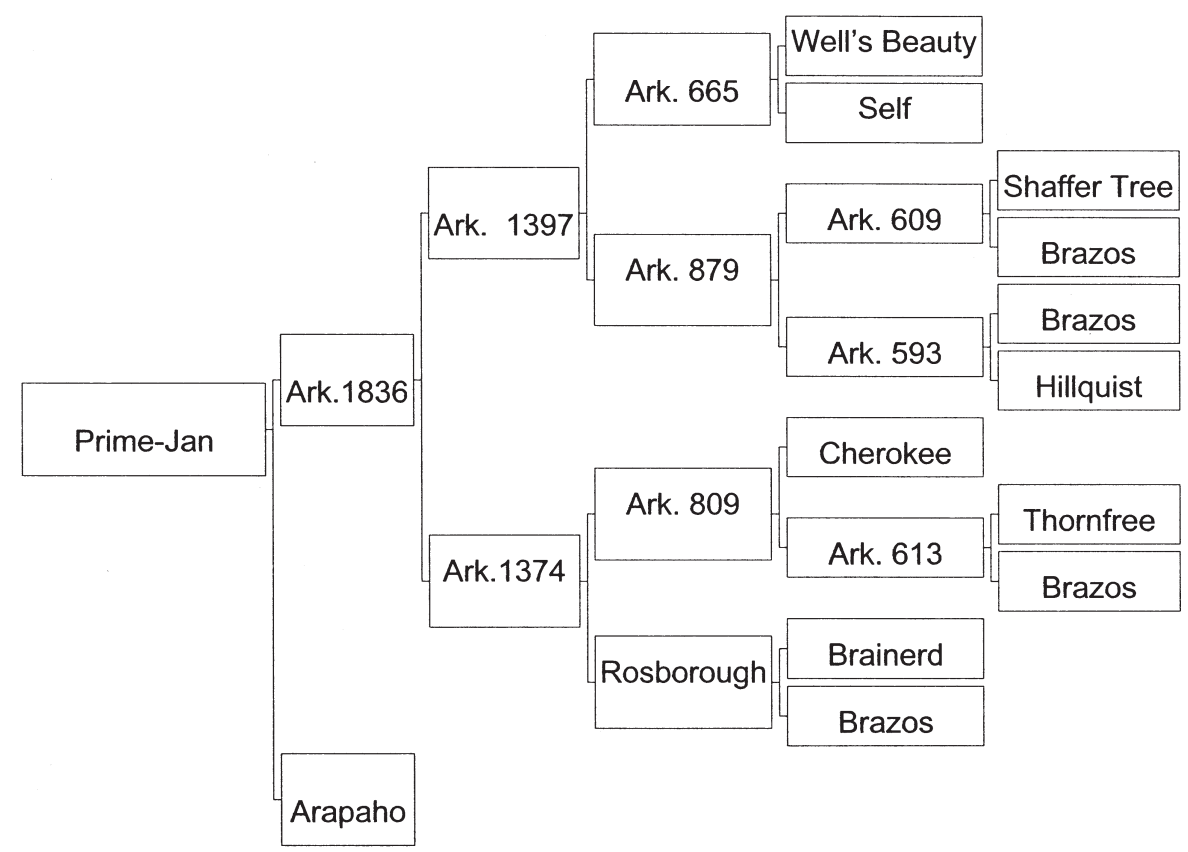

Fig. 1. Pedigree of 'Prime-Jan' primocane-fruiting blackberry. 


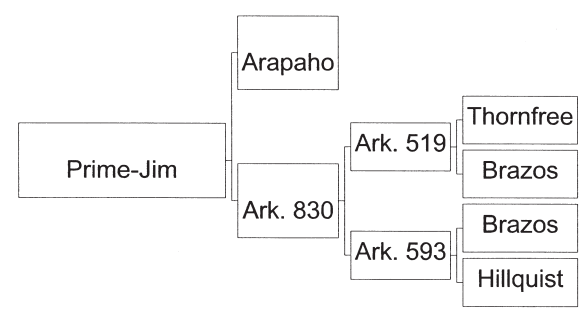

Fig. 2. Pedigree of 'Prime-Jim' primocane-fruiting blackberry.

any year. All plots were irrigated as needed using overhead sprinkler irrigation.

Data collected included primocane first date of flowering and first ripe fruit date. Also, floricane fruit ratings were taken for all genotypes based on a rating scale of 1 to 10 , where $10=$ best, for 5 years (1999-2003) for firmness (as measured subjectively by hand in the field on eight to ten berries, with rating of 10 indicating very firm) and flavor (subjectively rated by tasting berries in the field). Plant ratings for vigor ( 1 to 10 with a rating of 7 to 10 acceptable), health (1 to 10 with $10=$ excellent health), and erectness (1 to 10 with $10=$ very erect) were conducted one time each year for 5 years (1999-2003) during the floricane-fruiting season. All ratings were conducted by J.R. Clark. Winter injury was evaluated (seen as bud or cane injury) each year at the time of early floricane fruit ripening (early June).

Additionally, replicated trials were established at research stations in Clarksville (Fruit Substation) and Hope (Southwest Research and Extension Center) [southwestern Arkansas, lat. $33^{\circ} 42^{\prime} 30^{\prime}$ and long. $93^{\circ} 33^{\prime} 0^{\prime}$; USDA hardiness zone $8 \mathrm{a}$, soil type Bowie fine sandy loam (Fragic Palendults)] in 1999 and 2002. These trials consisted of four replications at each location. Plots in these trials were $3.1 \mathrm{~m}$ in length containing five plants produced from root cuttings spaced at $0.6-\mathrm{m}$ intervals. The cultivars Arapaho, Choctaw and Ouachita were included for comparison in the 1999 trial and all but 'Choctaw' were included in the 2002 trial. Cultural management of these trials were the same as described previously, with the exception of drip irrigation being used at Hope and for the 2002 replicated planting at Clarksville. Data for $10 \%$ and $50 \%$ floricane bloom, and floricane first, peak, and last harvest dates were recorded in 2001-02 for the 1999 trial, in 2003 for the 2002 trial, and were averaged over years for each trial at Clarksville.

In total, 25 berries were collected from a single replication of one floricane harvest of the Clarksville trial and frozen. Berries were subsequently thawed and a blender was used to extract 25 seed (endocarp) samples that were heated to $70{ }^{\circ} \mathrm{C}$ for $24 \mathrm{~h}$ and weighed. Berry weight was obtained by compositing and averaging the weight of 25 berries per replication on each harvest date at each location. Data including berry weight, and total floricane and primocane yields were collected from the replicated plantings in 2000-02, and from all locations in 2003, and were analyzed separately by year and location using PROC GLM (SAS Institute, 1989). One exception to this data collection was that no primocane crop data were collected at Hope for the 1999 trial (fruiting years 2000-02).

Testing was also done at Aurora, Ore., at the Oregon State University North Willamette Research and Extension Center [northwest Oregon, lat. $45^{\circ} 16^{\prime} 55^{\prime} \mathrm{N}$ and long. $122^{\circ} 45^{\prime} 01^{\prime} \mathrm{W}$; USDA hardiness zone 8; fine-loamy, mixed mesic Aqualtic Haploxeralfs] in plots established in 2000. While Aurora, Ore., and Hope, Ark., are in the same USDA hardiness zone, they have very different climates. The Oregon site, in the Willamette Valley, has a Mediterranean climate. Most precipitation (1041 mm. $\mathrm{yr}^{-1}$ ) falls between November and May with almost no summer rain. Temperatures are mild year round and during this study seldom fell more than a few degrees below freezing in the winter and were seldom above $32{ }^{\circ} \mathrm{C}$ in the summer. This trial consisted of two 'Prime-Jan' and one 'Prime-Jim' plots $6.1 \mathrm{~m}$ in length with plants at $1.1 \mathrm{~m}$ spacing. Yield and berry weight data were collected on primocanes only in this trial in 2002 and 2003, along with observations on dates of flowering and fruiting. These data were not statistically analyzed.

Relative floricane yields of 'Prime-Jan' ('APF-8') and 'Prime-Jim' ('APF-12') compared to named cultivars in the replicated trials varied with location (Tables 1 and 2). The highest floricane yields were recorded in 2003 at Hope and Clarksville and were similar (Hope) or exceeded (Clarksville) the named cultivars. Yields of primocane fruiting genotypes were generally similar to that of the named cultivars in the 1999-established trials. The exception occurred in 2002 at Clarksville where a spring freeze severely reduced yields of the primocane fruiting types and 'Arapaho'. These data indicate that the primocane-fruiting genotypes have the potential to produce substantial floricane yields in addition to fruiting on primocanes.

Average floricane berry weight of 'PrimeJan' ranged from 3.7 to $6.4 \mathrm{~g}$ in the replicated trials with an overall average of $5.1 \mathrm{~g}$ for all trials (Tables 1 and 2). 'Prime-Jim' ranged from 4.0 to $5.5 \mathrm{~g}$ with an overall average of $4.9 \mathrm{~g}$ (Tables 1 and 2) Both primocane genotypes were statistically similar or lower in berry weight compared to the named cultivars depending on year or location (Tables 1 and 2).

Primocane-fruiting performance for 'Prime-Jan' and 'Prime-Jim' varied greatly with location. The performance of these genotypes in Oregon was exceptional compared to either location in Arkansas. Primocane yields in Oregon ranged from 4,103 to $17,179 \mathrm{~kg} \cdot \mathrm{ha}^{-1}$ for 'Prime-Jan', and from 1,661 to 20,010 $\mathrm{kg} \cdot \mathrm{ha}^{-1}$ for 'Prime-Jim' depending on year (Table 3). However, at Clarksville the total primocane yield for 'Prime-Jan' ranged from 412 to $3,048 \mathrm{~kg} \cdot \mathrm{ha}^{-1}$ and for 'Prime-Jim' 220 to $1,835 \mathrm{~kg} \cdot \mathrm{ha}^{-1}$. At Hope the yields were

Table 1. Floricane yield and berry weight of two primocane fruiting and three floricane-fruiting blackberry cultivars in replicated plantings established at two locations (Clarksville and Hope) in Arkansas in 1999.

\begin{tabular}{lccccccc}
\hline & \multicolumn{3}{c}{ Yield $\left(\mathrm{kg} \cdot \mathrm{ha}^{-1}\right)$} & & \multicolumn{3}{c}{ Wt/berry $(\mathrm{g})$} \\
\cline { 2 - 4 } Cultivar & 2000 & 2001 & 2002 & & 2000 & 2001 & 2002 \\
\hline Clarksville & $4,994 \mathrm{~b}^{\mathrm{z}}$ & $4,754 \mathrm{bc}$ & $1,603 \mathrm{~b}$ & & $5.2 \mathrm{a}$ & $4.9 \mathrm{~b}$ & $3.7 \mathrm{~b}$ \\
Prime-Jan & $4,715 \mathrm{~b}$ & $5,905 \mathrm{bc}$ & $3,135 \mathrm{~b}$ & & $4.9 \mathrm{a}$ & $5.2 \mathrm{~b}$ & $4.0 \mathrm{~b}$ \\
Prime-Jim & $5,886 \mathrm{a}$ & $6,811 \mathrm{~b}$ & $6,659 \mathrm{a}$ & & $5.8 \mathrm{a}$ & $6.4 \mathrm{a}$ & $4.7 \mathrm{a}$ \\
Ouachita & $2,699 \mathrm{c}$ & $3,527 \mathrm{c}$ & $3,171 \mathrm{~b}$ & $5.0 \mathrm{a}$ & $5.3 \mathrm{~b}$ & $4.2 \mathrm{ab}$ \\
Arapaho & $5,697 \mathrm{a}$ & $10,623 \mathrm{a}$ & $4,597 \mathrm{ab}$ & $5.1 \mathrm{a}$ & $5.6 \mathrm{~b}$ & $4.1 \mathrm{ab}$ \\
Choctaw & $5,768 \mathrm{~b}$ & $6,315 \mathrm{c}$ & $4,738 \mathrm{~b}$ & & $3.1 \mathrm{~b}$ & $5.5 \mathrm{bc}$ & $5.0 \mathrm{a}$ \\
Hope & $8,818 \mathrm{~b}$ & $9,678 \mathrm{bc}$ & $6,167 \mathrm{~b}$ & & $4.5 \mathrm{a}$ & $4.9 \mathrm{c}$ & $4.0 \mathrm{~b}$ \\
Prime-Jan & $9,915 \mathrm{ab}$ & $11,184 \mathrm{~b}$ & $10,931 \mathrm{a}$ & & $5.9 \mathrm{a}$ & $5.5 \mathrm{~b}$ & $5.0 \mathrm{a}$ \\
Prime-Jim & $7,227 \mathrm{~b}$ & $7,365 \mathrm{c}$ & $9,516 \mathrm{a}$ & $5.6 \mathrm{a}$ & $4.6 \mathrm{c}$ & $4.0 \mathrm{~b}$ \\
Ouachita & $13,635 \mathrm{a}$ & $16,891 \mathrm{a}$ & $6,514 \mathrm{~b}$ & $4.6 \mathrm{a}$ & $8.6 \mathrm{a}$ & $4.0 \mathrm{~b}$ \\
Arapaho & & & &
\end{tabular}

${ }^{\mathrm{z}}$ Mean separation within columns and locations by $t$ test $(P \leq 0.05)$.

Table 2. Floricane and primocane yield and berry weight of two primocane-fruiting and two floricanefruiting blackberry cultivars for 2003 in replicated plantings established at two locations in Arkansas in 2002 .

\begin{tabular}{lcc}
\hline Cultivar & Yield $\left(\mathrm{kg} \cdot \mathrm{ha}^{-1}\right)$ & Wt/berry $(\mathrm{g})$ \\
\hline Floricane-Clarksville & & \\
Prime-Jan & $12,751 \mathrm{ab}^{\mathrm{z}}$ & $6.4 \mathrm{a}$ \\
Prime-Jim & $14,059 \mathrm{a}$ & $5.5 \mathrm{~b}$ \\
Ouachita & $12,261 \mathrm{~b}$ & $6.5 \mathrm{a}$ \\
Arapaho & $7,793 \mathrm{c}$ & $4.6 \mathrm{c}$ \\
Floricane-Hope & & $6.1 \mathrm{~b}$ \\
Prime-Jan & $17,645 \mathrm{a}$ & $5.2 \mathrm{c}$ \\
Prime-Jim & $17,115 \mathrm{a}$ & $6.5 \mathrm{a}$ \\
Ouachita & $18,347 \mathrm{a}$ & $5.2 \mathrm{c}$ \\
Arapaho & $13,353 \mathrm{a}$ & $4.1 \mathrm{a}$ \\
Primocane-Clarksville & & $3.3 \mathrm{~b}$ \\
Prime-Jan & $2,750 \mathrm{a}$ & $5.2 \mathrm{a}$ \\
Prime-Jim & $1,835 \mathrm{~b}$ & $3.9 \mathrm{a}$ \\
Primocane-Hope & & $594 \mathrm{a}$ \\
Prime-Jan & $164 \mathrm{a}$ & \\
Prime-Jim & & \\
\hline
\end{tabular}

${ }^{\mathrm{z}}$ Mean separation within columns and locations by $t$ test $(P \leq 0.05)$. 
substantially lower than those for Clarksville (Table 3 ). Similarly, berry weights for both genotypes were substantially higher in Oregon, often two to three times larger. The reduction in yield, berry weight and quality of the primocane genotypes in Arkansas was attributed to high temperatures during bloom and fruit development from late July through early September where daytime temperatures exceeded about $29^{\circ} \mathrm{C}$ for 5 or more consecutive days. The poorest performance occurred at Hope, where temperatures were consistently higher than either Clarksville or Aurora. These results indicated that these primocane fruiting genotypes lack heat tolerance and may possess greater adaptation to areas with cooler summer temperatures such as the upper midwestern U.S., the northeast, and the northwestern U.S. These findings show a substantial limitation of the primocane-fruiting genotypes in Arkansas and potentially in other areas with comparable summer temperatures.

Fruit of 'Prime-Jan' and 'Prime-Jim' are blocky, conical and attractive with a glossy, black finish. Fruit shape varies on primocanes and quality factors including glossiness and color are affected by heat. Doubled fruit have also been observed on primocanes in Arkansas each year. Firmness of floricane fruit was rated in the field at maturity (glossy-black color) and ratings of fruit firmness were lower for both of these genotypes than either 'Arapaho' or 'Ouachita', but comparable to or greater than those of 'Choctaw' (Table 4). Soluble solids concentration for floricane fruit over 4 years averaged 9.6\% for 'Prime-Jan', and 7.9\% for ‘Prime-Jim' (Table 4). 'Prime- Jan' was comparable to other cultivars but 'Prime-Jim' was lower in soluble solids content. Primocane fruit were observed to be higher than floricane fruit in soluble solids in some years (data not shown). Although flavor rating average of 7.2 for both 'Prime Jan' " and Prime-Jim' was lower than some comparison cultivars, it was comparable to that of 'Arapaho', a cultivar rated very high among most evaluators of berry flavor. Postharvest evaluations (berry leakage, softness, and decay after $7 \mathrm{~d}$ of storage at $5{ }^{\circ} \mathrm{C}$ ), indicated that 'Prime-Jan' and 'Prime-Jim' stored comparably to the thorny cultivars Shawnee and Kiowa and the thornless cultivar Triple Crown, but did not store as well as 'Apache, 'Navaho', or 'Ouachita'. Therefore, fruit of 'Prime-Jan' and 'PrimeJim' may not be suitable for long-distance shipping. Seed weight, an indicator of seed size, is important to consumers with a preference for small-seeded blackberries. Dry seed

Table 3. Primocane yield and berry weight of primocane-fruiting blackberry cultivars in a replicated planting established in 1999 at the University of Arkansas Fruit Substation, Clarksville, and in 2000 at the Oregon State University North Willamette Research and Extension Center, Aurora.

\begin{tabular}{lcccccc}
\hline Cultivar & \multicolumn{3}{c}{ Yield $\left(\mathrm{kg}^{\circ} \mathrm{ha}^{-1}\right)$} & \multicolumn{3}{c}{ Wt/berry $(\mathrm{g})$} \\
\hline Clarksville & 2000 & 2001 & 2002 & 2000 & 2001 & 2002 \\
\hline Prime-Jan & $412 \mathrm{a}^{2}$ & $2,398 \mathrm{a}$ & $3,048 \mathrm{a}$ & $2.0 \mathrm{a}$ & $3.5 \mathrm{a}$ & $3.7 \mathrm{a}$ \\
Prime-Jim & $220 \mathrm{a}$ & $229 \mathrm{~b}$ & $1,130 \mathrm{a}$ & $2.1 \mathrm{a}$ & $3.2 \mathrm{a}$ & $2.6 \mathrm{~b}$ \\
& & & & & & \\
Aurora $^{y}$ & 2002 & 2003 & & 2002 & 2003 & \\
\hline Prime-Jan $_{\text {Prime-Jim }}^{4,103}$ & 17,179 & & 10.6 & 7.8 & \\
\hline
\end{tabular}

${ }^{2}$ Mean separation within columns by $t$ test $(P \leq 0.05)$.

${ }^{y}$ Single-plot data from Oregon and no statistical analysis conducted. Primocanes only were fruited each year. Data for 2002 through 9 Oct.; data for 2003 through 20 Oct. At each of these dates additional unripe fruit and flowers were present on the plants suggesting higher total yields could have been attained for the entirety of the season.

Table 4. Plant and fruit characteristics of five blackberry cultivars at the University of Arkansas Fruit Substation, Clarksville.

\begin{tabular}{|c|c|c|c|c|c|}
\hline \multirow[b]{2}{*}{ Characteristic } & \multicolumn{5}{|c|}{ Cultivar } \\
\hline & Prime-Jan & Prime-Jim & Ouachita & Arapaho & Choctaw \\
\hline \multicolumn{6}{|l|}{ Floricane bloom date ${ }^{z}$} \\
\hline $10 \%$ bloom & 22 Apr. & 21 Apr. & 29 Apr. & 28 Apr. & 22 Apr. \\
\hline $50 \%$ bloom & 28 Apr. & 26 Apr. & 7 May & 4 May & 26 Apr. \\
\hline \multicolumn{6}{|l|}{ Floricane bloom date ${ }^{y}$} \\
\hline $10 \%$ bloom & 24 Apr. & 23 Apr. & 29 Apr. & 29 Apr. & --- \\
\hline $50 \%$ bloom & 29 Apr. & 28 Apr. & 13 May & 13 May & --- \\
\hline \multicolumn{6}{|l|}{ Floricane harvest date $(2000-02)^{\mathrm{z}}$} \\
\hline First & 8 June & 3 June & 12 June & 6 June & 31 May \\
\hline Peak & 17 June & 13 June & 19 June & 11 June & 6 June \\
\hline Last & 6 July & 3 July & 20 July & 7 July & 23 June \\
\hline \multicolumn{6}{|l|}{ Floricane harvest date $(2003)^{\mathrm{y}}$} \\
\hline First & 12 June & 10 June & 16 June & 9 June & -- \\
\hline Peak & 23 June & 16 June & 30 June & 16 June & --- \\
\hline Last & 11 July & 8 July & 21 July & 8 July & --- \\
\hline Primocane first bloom date ${ }^{x}$ & 16 June & 17 June & --- & --- & --- \\
\hline Primocane first ripe fruit date ${ }^{\mathrm{x}}$ & 18 July & 17 July & --- & --- & \\
\hline \multicolumn{6}{|l|}{ Fruit } \\
\hline Firmness $^{\mathrm{xw}}$ & $6.8(0.4)$ & $7.0(0.3)$ & $8.2(0.2)$ & $8.2(0.2)$ & $6.2(0.2)$ \\
\hline Flavor $^{\mathrm{xw}}$ & $7.2(0.2)$ & $7.2(0.2)$ & $8.0(0.0)$ & $7.6(0.2)$ & $7.8(0.2)$ \\
\hline Seed dry weight ${ }^{v}$ (mg/seed) & 3.2 & 2.1 & 3.9 & 2.8 & -- \\
\hline Soluble solids $(\%)^{\mathrm{u}}$ & 9.6 & 7.9 & 9.4 & 9.7 & 9.3 \\
\hline \multicolumn{6}{|l|}{ Plant ${ }^{\mathrm{xw}}$} \\
\hline Vigor & $7.2(0.4)$ & $7.8(0.4)$ & $8.0(0.3)$ & $7.2(0.5)$ & $7.2(0.4)$ \\
\hline Health & $8.2(0.4)$ & $8.2(0.2)$ & $8.4(0.2)$ & $7.6(0.5)$ & $7.2(0.2)$ \\
\hline Erectness & $7.6(0.7)$ & $8.4(0.2)$ & $8.6(0.2)$ & $7.6(0.2)$ & $7.2(0.5)$ \\
\hline
\end{tabular}

${ }^{2}$ Means of 3 years, 2003-2002, with data collected from the 1999-established replicated plots.

${ }^{y}$ Means of 1 year, 2003, with data collected from the 2002-established replicated plots.

${ }^{x}$ Means of 5 years, 1999 through 2003, with data collected from the observational plots; \pm the standard deviation (no standard deviation provided for the bloom and ripe dates).

${ }^{\text {w }}$ Rating scale of 1 to 10 where $10=$ best.

vAverage weight of 25 seeds; seeds were collected, frozen, extracted, dried, and weighed in 2003.

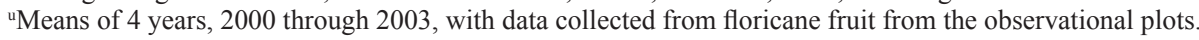


to 'Arapaho', and 6 to $9 \mathrm{~d}$ earlier than 'Ouachita' (Table 4). Peak and last harvest dates had similar trends.

Primocane first bloom dates were very similar for 'Prime-Jan' and 'Prime-Jim', 16 and 17 June, respectively (Table 4). However, high temperatures reduced blooming from August until mid-September, when substantial flower development resumed (data not shown). At Hope in August, high temperatures resulted in profound reductions in flowering, followed by development of very few late-season flowers in some years (data not shown). In Oregon, primocane flowering began in July, but beginning bloom date varied greatly among individual primocanes; while some began in July, others were just beginning to flower in late October. Flowering continued until frost and did not appear to decline in late summer in this moderate climate. In 2001 in Geneva, N.Y., primocane flowering on both 'Prime-Jan' and 'Prime-Jim' was noted to begin in late July and in 2004 fruit ripened about 1 Sept. (Courtney Weber, personal communication).

Average primocane first ripe fruit dates for both genotypes at Clarksville occurred in mid July (Table 4). Fruiting continued until frost but was greatly reduced by mid August (data not shown). At Hope, the first ripe fruit were usually observed about $10 \mathrm{~d}$ earlier than at Clarksville (data not shown). In Oregon, first ripe fruit of both genotypes occurred about 1 Sept., and ripening continued until frost (data not shown). A large amount of green fruit and some flowers were observed each year in late October in Oregon. Therefore, the yield potential in Oregon may be higher than reflected in the data presented if an artificial environment such as high tunnels was used to extend the fruiting season.

Canes of 'Prime-Jan' and 'Prime-Jim' are thorny and erect. Average erectness rating for 'Prime-Jan' was 7.6 and for 'Prime-Jim' 8.4 (Table 4). If primocanes are tipped at 1.0 to $1.3 \mathrm{~m}$ to control length and encourage lateral branching, 'Prime-Jan' and 'Prime-Jim' can be grown in a hedgerow without trellis support. However, support of floricanes and primocanes during fruiting is recommended as this practice can prevent canes from falling over due to wind or heavy crop loads. Vigor ratings of 'PrimeJan' and 'Prime-Jim' were good, and generally comparable to the comparison cultivars (Table 4). Average health ratings for both primocane genotypes were also good (Table 4). No orange rust [caused by Gymnoconia nitens (Shwein.) F. Kern \& H.W. Thurston] was observed on either 'Prime-Jan' or 'Prime-Jim' in any evaluations even though infected plants were seen within $30 \mathrm{~m}$ of plots of these genotypes in each year of evaluation. Both genotypes showed rare instances of anthracnose on berries in the selection observation planting in evaluations where a single spray of lime sulfur was applied. Reaction of 'Prime-Jan' and 'Prime-Jim' to rosette-double blossom [Cercosporella rubi (Wint.) Plakidas] was evaluated at Poplarville, Miss, and both were found to be susceptible to this disease (Steve Stringer, personal communication). However, double blossom should not be a concern if these genotypes are used for primocane-fruiting only since the disease develops only on floricane buds the year after infection. In observational plots in West Lafayette, Ind., it was observed that Japanese beetles (Popillia japonica Newman) fed heavily on primocane blooms of both cultivars in mid to late summer (Bruce Bordelon, personal communication). Growers in areas where this insect is common should be aware of potential crop reductions due to flower damage.

Minimum mid-winter low temperatures at Clarksville during evaluation ranged from -7.8 ${ }^{\circ} \mathrm{C}$ (1999-2000 winter) to $-12.2^{\circ} \mathrm{C}(2002-03$ winter). A late-winter freeze occurred in 2002, with a low of $-13.4^{\circ} \mathrm{C}$ on $3 \mathrm{Mar}$. and the floricane crop was reduced for primocane-fruiting genotypes, with 'Prime-Jan' experiencing a greater yield reduction than 'Prime-Jim' (Table 1). However, yields of all other comparison cultivars except 'Ouachita' were also reduced in comparison to the previous year. The largest yields were experienced in 2003 following the mid-winter low of $-12.2^{\circ} \mathrm{C}$, however, and we are confident of floricane hardiness at least to that level when plants are fully dormant. Except in Spring 2002, winter injury to canes was not observed. Hardiness limitations in overwintering canes in very cold climates can prevent blackberries from being grown in these climates. The primocane-fruiting habit has the potential to eliminate this concern since overwintering of canes to attain fruit production is not required with these genotypes.

Root cutting sprouting of 'Prime-Jan' and 'Prime-Jim' " under greenhouse conditions after placing in commercial potting soil has been very good, usually $>80 \%$ successful, and similar to other thorny cultivars (data not shown). Therefore, growers or nurserymen using root cuttings should be successful using root cuttings for planting establishment or for licensed propagation of the primocane cultivars.

Chilling requirements for floricanes of 'Prime-Jan' and 'Prime-Jim' have not been conclusively determined. However, observations on budbreak on detached lateral shoots forced in a greenhouse after increasing levels of field chilling indicated that 'Prime-Jim' had a low chilling requirement (100 to $300 \mathrm{~h}$ below $7^{\circ} \mathrm{C}$ ), possibly similar or lower than that for 'Kiowa' (Carter and Clark, 2003). During this investigation conducted at Hope, Ark., 'Prime-Jim was observed to have green bud tips and some flower buds present throughout the winter of 2001-02, indicating it may never have entered full dormancy. Further observations in 2002-03 comparing budbreak of detached lateral shoots of 'Prime-Jan' and 'Prime-Jim' collected at increasing chill-level intervals, indicated that 'Prime-Jan' may have a low chilling requirement also (data not shown). Therefore, these cultivars may be utilized in low-chill areas for their floricane-fruiting potential. However, the fruiting of these cultivars on primocanes eliminates the requirement for chilling for fruit production on current-season canes, and this trait could stimulate expansion of blackberry production into low- to no-chill areas of the world.

A question that arises concerning man- agement of primocane blackberries centers on the effect of single (primocane only) or double (floricane and primocane) cropping on primocane crop. In a study conducted on these genotypes in Arkansas in 2000, it was found that single vs. double-cropping did not affect primocane yield (Drake and Clark, 2003). The effect of tipping primocanes to affect time of flowering and fruiting was also investigated.. Yield and berry size were similar on tipped (tipped when primocanes reached $1 \mathrm{~m}$ in length) and untipped primocanes, and date of fruiting was not affected by tipping. Similar responses were observed on the tipped and nontipped observational plots at Clarksville (no data shown). However, effect of these treatments on these genotypes in more moderate summer temperatures may be entirely different and it is suggested that evaluations of single vs. double cropping, along with tipping effects, be examined in a range of climates. Likewise, fertilization practices must be evaluated for these cultivars, with a focus on the rate and timing of nitrogen applications. In 2003 the plots fertilized in early July following completion of the floricane crop were observed to maintain healthier foliage and produce more cane growth than had been observed in years when this application was not made.

'Prime-Jan' and 'Prime-Jim' offer an entirely new type of blackberry. The unique primocane-fruiting habit has the potential to greatly change blackberry production in many environments. These cultivars are recommended for home-garden production, and limited commercial trial. We believe that these cultivars may have some commercial potential for local production where shipping of fruit is not required, but do not recommend the fruit be shipped based on current postharvest data. The substantial reduction in fruiting potential and quality in high heat conditions should be noted by those considering trial of these cultivars in areas with a similar climate.

\section{Availability}

An application for a U.S. plant patent has been filed for 'Prime-Jan' and 'Prime-Jim'. A list of nurseries licensed to propagate and sell 'Prime-Jan' and 'Prime-Jim' can be obtained from J.R.C., 316 Plant Science, Dept. of Horticulture, Univ. of Arkansas, Fayetteville, AR 72701 (jrclark@uark.edu).

\section{Literature Cited}

Carter, M.. and J.R. Clark. 2003. Chilling response of Arkansas blackberry cultivars. Horticultural Studies 2002. Ark. Agr. Expt. Sta. Res. Ser. 506:65-67.

Drake, C.A. and J.R. Clark. 2002. Effects of pruning and cropping on field-grown primocane-fruiting blackberries. HortScience 38:260-262.

Lopez-Medina, J., J.N. Moore, and R.W. McNew. 2000. A proposed model for inheritance of primocane fruiting in tetraploid erect blackberry. J. Amer. Soc. Hort. Sci. 125:217-221.

SAS Institute Inc. 1989. SAS/STAT user's guide, version 6, 4th ed. vol. 2. SAS Institute Inc., Cary, N.C. 